\title{
PERAN ULAMA DALAM MASYARAKAT ACEH DARI MASA KEMASA
}

\author{
Jon Paisal \\ STAIN Tengku Dirundeng Meulaboh \\ E-mail:jonpaisal2@gmail.com
}

\begin{abstract}
Abstrak
Ulama merupakan sebagai pewaris para Nabi untuk menyebarkan ajaran Islam melalui aktifitas dakwah, dalam kapasitas ulama sebagai Warasatul-anbiya (Pewaris Nabi), seorang ulama sudah seharusnya berperan untuk melanjutkan tongkat estafet misi kenabian dalam melanjutkan risalah Nabi, setidaknya harus dapat mengembankan peran tablig, tabyin, tahkim dan uswah kepada umat manusia. Tujuan penelitian ini untuk menemukan peran Ulama didalam masyarakat Aceh dari masa kemasa. Dalam penelitian ini menggunakan metode studi kepustakaan datanya bersumber dari buku, jurnal, dan artikel yang dapat memberikan informasi terhadap peran ulama dalam masyarakat aceh dari masa kemasa. Hasil penelitian menunjukkan bahwa ulama telah banyak berperan dalam segala aspek kehidupan masyarakat di Aceh dari masa kemasa, diantaranya. Peran ulama sebagai guru dalam masyarakat, ulama berperan dalam melawan Belanda dan konflik-konflik di Aceh, ulama mempunyai peran pasca Aceh konflik. Peranan Ulama terhadap adat dalam masyarakat sampai sekarang.
\end{abstract}

Kata kunci: Peran Ulama, Aceh, Masyarakat

\begin{abstract}
Ulama are the inheritors of the Prophets to spread Islamic teachings through da'wah activities, in the capacity of the ulama as Warasatul-anbiya (heir of the Prophet), an ulama should have a role to continue the baton of the prophetic mission in continuing the Prophet's message, at least he must play the role of tablig, tabyin, tahkim and uswah to mankind. This study aims to discover the role of ulama in Acehnese society from time to time. In this study, using the literature study method, the data comes from books, journals, and articles which can provide information on the role of ulama in Acehnese society from time immemorial. The results showed that the ulama had played a role in all aspects of community life in Aceh from time to time, including. The role of the ulama as a teacher in society, the ulama played a role in fighting the Dutch and the conflicts in Aceh, the ulama had a role in the post-Aceh conflict. The role of Ulama towards adat in society until now.
\end{abstract}

Keywords: Role, Ulama, Aceh, Society 


\section{PENDAHULUAN}

Ulama dalam pandangan sejarah lebih dominan dikenal sebagai petunjuk bagi umat, disebabkan olaeh ulama telah banyak peranannya melalui dakwah memberikan pengetahuan kepada umat manusia kejalan yang benar. Ulama memiliki sikap sederhana dan keiklasan melalui sikap tersebut menjadi faktor pendukung terhdapa melahirkan Haman resource yang efesien serta dapat bersaying pada dunia global. ${ }^{1}$ Jika dari dilihat pada konteks sejarah ulama mempunyai peran begitu besar, ulama dan pengambil kebijakan dipemerintahan mereka mendapatkan atensi yang memadai dalam Islam dan mereka mendapatkan kedudukan yang istimewa dalam masyarakat. ${ }^{2}$ Sabda Nabi Muhammad SAW:

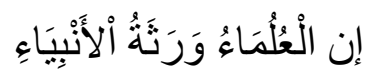

Artinya: Sesungguhnya para Ulama adalah pewaris para Nabi. (Sunan Abu Daud. Hadis no 3641). ${ }^{3}$

Ulama merupakan sebagai pengganti para Nabi untuk melanjutkan perjuangan Islam melalui dakwah dalam membina manusia dari berbagai aspek kehidupan, saat para Nabi telah tiada, maka tugas para Nabi menjadi tanggung jawab para ulama, yaitu dalam hal tabligh atau berdakwah menyebarkan Islam sebagai ajaran yang benar yang dibawa Nabi. ${ }^{4}$ Dalam kapasitas ulama sebagai Warasatul-anbiya (Pewaris Nabi), seorang ulama berperan sebagai pelanjut tongkat estafet misi kenabian dalam melanjutkan risalah Nabi, setidaknya harus mengembankan peran tablig, tabyin, tahkim dan uswah dalam masyarakat. ${ }^{5}$

Pada masa kerajaan Sultan Iskandar Muda daerah Aceh pernah dikenal dareah Kerajaan Islam terbesar di dunia ini. Dikenalnya kehebatan Aceh oleh manca dunia tak lepas dari kontibusinya ulama dari berbagai perannya ulama dapat bermanfaat untuk kerajaan Aceh, peranan ulama Aceh tidak berhenti disitu saja, ulama secara

\footnotetext{
${ }^{1}$ Muhammad Thalal, dkk, Ulama Aceh Dalam Melahirkan Human Resource di Aceh, (Banda Aceh: Yayasan Aceh Mandiri, 2010), 13.

2 Sri Suryanta, Dinamika Peran Ulama, (Yogyakarta: AK.Group, UIN Ar-Raniry Banda Aceh, 2008, Cet, I), 29.

${ }^{3}$ Sunan Abu Daud, Terj. Muhammad Nashiruddin Al-Albani, (Jakarta: Pustaka Azzam, 2007, Cet, Ke-II), 654 \& 655. 2009), 1

${ }^{4}$ Harmen Nuriqmar, Keramat Ulama Aceh, (Banda Aceh: Badan Arsip Perpustakaan Aceh, ${ }^{5}$ Sri Suryanta, Dinamika Peran Ulama di Aceh, 175.
} 
berkelanjutan berperan terhadap kemajuan Aceh dan kebudayaan dalam rangka membangun perdaban untuk kemajuan di Aceh. ${ }^{6}$ Dalam hal ini dapat dilihat disisi historis menacapai puncak kemajuan Kerajaan diAceh Darusalam dimasa pemerintahan SultanIskandar Muda.

Para alim ulama memiliki pengetahuan agama yang tinggi, seperti misalnya fikih, aqidah, serta pengetahuan tentang tasawwuf, maka akan menjadi rujukan bagi masyarkat muslim dalam menalar dan membuat sebuah (ijtihad) mengenai agama sesuai dengan pendapat ulama, disebabkan kalangan masyarakat kurang ilmu pengetahuan tentang agama secara mendalam terhadap terhadap sesuatu persoalan berkaitan dengan agama dan oleh sebab itu dinajurkan untuk mengambil hasil pendapat seorang ulama. Maka oleh sebab itu kedudukan ulama secara pemikiran dan kemasyarakatan diakui dalam kehidupan masyarakat. ${ }^{7}$

Dalam masyarakat Aceh seseorang yang baru pulang dari pesantren atau dayah kebiasaannya dijuluki sebagai tengkuu, gelar tengku yang disandangkan terhadap individual tidak dilihat dari jangka waktu keberadaanya menunut ilmu disuatu dayah. Akan tetapi apibla ditinjau secara ilmiah gelar ulama yang diberikan kepada seseorang ia sudah lama menuntut ilmu dipesantren dan memiliki ilmu agama serta wawasan yang luas dan mempunyai daya untuk mempengaruhi masyarakat dengan ilmu yang dimiliki dan kontribusinya terhadap masyarakat. Karena ulama merupakan orang yang beriman dan bertaqwa, taat pada agama, dan mempunyai akhlak yang mulia sehingga dengan karakter dimiliki oleh ulama akan mempermudah dalam menyeru umat kepada kebaiakan dan meninggalkan perbuatan dosa. seccara umum ulama memimpin pesantren atau dayah meskipun ada sebagian dari mereka tidak memimpin dayah. Kebiasaannya ulama yang memimpin dayah keulamaan masyarakat menjulukinya sebagai gelar Aboen, Teungku Chiek, atau Abu. ${ }^{8}$

\footnotetext{
${ }^{6}$ Muhammad Thalal, dkk. Ulama Aceh dalam melahirkan Human Resource di Aceh, 3.

${ }^{7}$ Azyumardi Azra, Ulama, Politik dan Modernisasi, dalam Ulumul Qur'an No. 7 vol. II, 1990, 4

${ }^{8}$ Rusdi Sufi, Kiprah Ulama Aceh, Pada Masa Revolusi Kemerdekaan, 7.
} 


\section{LANDASAN TEORI}

\section{Pengertian Ulama}

Secara etimologi kata ulama berasal dari bahasa Arab, yaitu 'ulama' (العلماء) bentuk jamak dari kata 'a'limu' (علم) artinya seorang mempunyai pengetahuan atau seseorang memiliki ilmu pengetahuan yang dalam. ${ }^{9}$ Sayid Qutub dalam pendaptnya“Ulama merupakan seorang yang memikirkan umat dan memahami AlQur'an"10 seorang ulama juga diartikan sosok yang mempunyai wawasan yang luas dan ilmu agama secara mendalam. ${ }^{11}$ Maka dari itu sosok ulama merupakan orang yang mempunyai ilmu dan wawasan tentang agama secara dalam dan mengamalkannya. ${ }^{12}$ Imam Al-Gghazali menuangkan pendapatnya tentang ulama dalam kitab "Ihya Ulumuddin" adanya perbedaan antara ulama dunia dan ulama akhira. Dalam pandangannya ulama dunia mereka lalai dalam mengurus hal-hal yang sifatnya duniawi saja, lebih mempudulikan kepentingan pribadi dari kepentingan orang banyak dan secara tamak mengumpul-ngumpulkan hartanya, meskipun ia mempunyai ilmu agama. Akan tetapi ulama pewaris Nabi adalah ulama yang memilki karakter mementingkan kepentingan umat manusia. ${ }^{13}$

Tidak hanya sekedar memiliki pengetahuan agama yang mendalam namun seorang ulama tidak serta merta menghukumi orang lain yang jahil sebagai orang yang mengkritik As-Sunnah, dan tidak semudahnya mengeluarkan sebuah fatwa, tidak pernah memberikan gelar ulama kepada diri sendiri karena ulama sosok yang tidak membanggakan atas ilmu yang dimiliki. ${ }^{14}$ Sosok ulama tidak hanya sekedar orang yang banyak ilmunya dan wawasan luas, akan tetapi ulama mempunyai rasa takut (kashyah) terhadap Allah Swt. ${ }^{15}$ Sebagaimana Allah SWT berfirman dalam Al-Qur'an:

\footnotetext{
${ }^{9}$ Muliadi Kurdi, Aceh di Mata Sejarawan, (Banda Aceh: LKAS 2009), 181.

${ }^{10}$ Sayid Qutub, ter. Fi Dzilali Al-qur'an Beirut Libanon Ihyau AlTurats Al Araby, v, 1967,

${ }^{11}$ Harmen Nuriqmar, Keramat Ulama Aceh, 1.

${ }^{12}$ Muhammad Thalal, dkk, Ulama Aceh Dalam Melahirkan Human Resource di Aceh, 6

${ }^{13}$ Muliadi Kurdi, Aceh di Mata Sejarawan, 182.

${ }^{14}$ Umar Hasyim, Mencari Ulama Pewaris Nabi, (Surabaya: PT Bina Ilmu, 1983, Cet. II),

${ }^{15}$ Muhammad Thalal, dkk, Ulama Aceh Dalam Melahirkan Human Resource di Aceh, 21.
} 698. 14. 


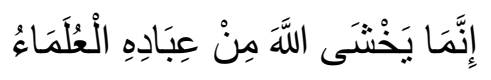

Artinya: Sesungguhnya yang takut kepada Allah di antara hamba-hambaNya, hanyalah ulama (Q.S Al-fathir: 28). ${ }^{16}$

Maka dari beberapa uraian sebelumnya dapat dipahami seorang ulama bukan hanya sebatas mempunyai ilmu secara mendalam dan memiliki wawasan akan tetapi ulama orang yang taat kepada Allah, dan taat mengaplikasikan ilmu pengetahuannya dalam mengajak masyarakat kejalan yang benar dari segala sudut aspek kehidupan manusia maka dengan akan menjadi orang yang bermanfaat dengan adanya peran dan kontribusinya terhadap umat, selain itu ulama juga orang yang banyak rasa takut terhadap Allah, mempunyai akhlak yang dapat diteladani segenap umat manusia lemah lembut dalam bertindak dan tidak bertabiat kasar. Seorang ulama mempunyai bawaan rasa sedih dan peduli terhadap umat, menunduk kepala dan berdiam diri. Dari keadaan, berpakaian tidak bermewah-mewah, cara jalan yang berwibawa dan banyak berdiam diri tidak dan tidak berbicara, orangorang ketika menatap ewajah seorang ulama akan dapat mengantarkan ingatannya kepada Allah Swt. wajahnya menggambarkan atas amalan atau perbuatan yang dilakukan. $^{17}$

\section{Konsep Masyarakat.}

Asal kata masyarakat berasal dari bahasa inggris yakni, "Society" yang artinya adalah "masyarakat" sedangkan kata "Society" tersebut berasal dari bahasa latin yang artinya "kawan" jika dilihat dari pengertian secara umum masyarakat adalah sekumpulan individu-individu yang terikat oleh sebuah aturan tertentu yang berupa norma-norma agama dan norma adat, didalam kehidupan bermasyarakat mempunyai tatanan hidup yang saling terikat antara satu sama lain untuk memperoleh kepentingan dalam hidup. ${ }^{18}$

Masyarakat di Aceh pada umumnya menjadikan ulama sebagai tempat rujukan dalam konteks spritual, bahkan dalam menyelesaikan persengketaanpun 700.

${ }^{16}$ Departemen Agama RI. Al-qur'an dan terjemahnya, (Jakarta: PT Bumi Restu, 1974),

${ }^{17}$ Ihya' Alghazali, Ihya' 'Ulumuddin terj. Ismail Yaqub, 281.

18 Donny Prasetyo, dkk, Memahami Masyarakat dan Perspektifnya. Jurnal, Available Online: https://dinastirev.org/JMPIS, diakses, 01 juli 2021 
melibatkan pendapat para ulama. Berbagai kalangan dalam masyarakat baik secara kelompok maupun indual mereka mempercayai ulama dengan memberikan fungsi sebagai guru yang dihormati. Dalam peneltian ini penulis akan memberikan hasil penelitian yang dapat dijadikan bahan bacaan dan wawasan terkait peranan dan kontribusi ulama Aceh terhadap masyarakat dari masa kemasa.

\section{METOLOGI PENELITIAN}

Jenis penelitian ini merupakan kepustakaan (libray researc) dalam mengumpulkan data pada penelitian ini merupakan hasil dari penelusuran berupa kitab-kitab, buku-buku, jurnal, dan artikel lain yang relevan untuk mendukung dalam menemukan informasi sebagai data yang diperlukan pada penelitian ini.

\section{HASIL DAN PEMBAHASAN}

Ulama mempunyai peran dan kontribusi terahap masyarakat dari masa kemasa, keberadaan ulama di tengah-tengah masyarakat telah mampu mengatasi berbagai persoalan yang di hadapi dalam kehidupan masyarakat mulai dari persoalaan keagamaan sampai kepada masalah sosial, sehingga masyarakat memposisikan ulama sebagai orang yang mulia. Pada akhir abad ke 16 hingga pertengahan abad $17 \mathrm{M}$, telah ada beberapa ulama yang dikenal pada masa kerajaan Aceh Darussalam. ${ }^{19}$ Misalnya Hamzah Fansury, Naruddin Ar- Raniry, Abdurrauf As-Singkily, Jalaluddin At-Turusany dan banyak ulama besar lainnya yang yang dikenal karena ulama sangat aktif untuk umat manusia. ${ }^{20}$ Dari hasil kajian ini dapat dilihat beberapa peran ulama dalam masyarakat Aceh diantaranya:

\section{Peran Ulama Sebagai Guru Dalam Masyarakat}

Sejak partama Islam datang daerah Aceh, telah banyak peran dan kontribusinya ulama terhadap masyarakat di Aceh sebagimana pandangan sejumlah ahli yang bahwasanya faktor jaringan ulama dapat memberikan sebuah warna yang intelektual daerah Aceh, keberadaan para ulama pada saat itu sangat diharapkan kalangan masayarakat gunanya untuk mengajari mereka tentang keislaman.

\footnotetext{
${ }^{19}$ Muliadi Kurdi, Aceh di Mata Sejarawan, 191.

${ }^{20}$ Zaini Abdullah, Muzakarah Pemikiran Ulma Aceh. (Banda Aceh: NASA, 2015), iv.
} 
Peran ulama daerah Aceh, khususnya pada konteks ilmu pendidika ulama memiliki peran sejak pertamanya terbentuk masyarakat Islam secara politik yaitu dimasa kesultanan daerah Aceh. Dapat dilihat pada saat kepemimpinan Malik AzZahir, samudra pasai. Pada tahun 1435 terdapat rekaman jejak kunjungan Ibnu Batutah yang bahwa raja yang mempunyai kekuasaan sangat taat pada beragama dan selalu berkonsultasi dengan ulama, Diantara meraka merupakan qadhi Sayyid Qadhi Syarif Amir Sayyid dari Shiraz dan Tajuddin dari Istafahan. ${ }^{21}$

Ulama telah banyak memberikan kontribusinya untuk membangun peradaban Islam dalam hal ini dapat dilihat dari banyak ulama-ulama pada masa lalu yang telah berkarya dalam berinovasi seperti penemuan dan pengembangan dalam bidang mesin dan teknologi, seprti Banu Musa pada abad 9 dan Al-Razzas Al-Jazari sekitar tahun 1200 menyusun berbagai teori tentang mesin dan teknologi. ${ }^{22}$ Dan masih banyak penemuan ulama yang ditulis para ulama dahulu kemudian dijadikan sebagai pedoman hidup oleh umat manusia dan para pemimpin di Aceh setelah berabad-abad pada masa tersebut. ${ }^{23}$

Dalam menjalankan fungsi ulama Aceh sebagai pendidik masyarakat hal ini dapat dilihat dalam aktifitas ulama di dua lembaga pendidikan norformal yaitu dayah dan meunasah, dua lembaga menjadi intsitusi terpenting pada masa tersebut yang dijadikan sebagai tempat untuk mendidik umat manusia tujuannya mengasah otak para generasi Islam menjadi khalifah yang baik dipermukaan bumi ini. ${ }^{24}$ Dalam konteks pendidikan seorang ulama pada masa dahuluny memilki posisi sebagai pimpinan pesantren, masyarakat posisikan ulama sebagai orang yang tepat dalam menfasirkan terakait sumber asli dalam ajaran Islam yaitui Al-qura'an serta hadis Nabi. selain dijadikan ulama sebagai pondasi dasar untuk mendapatkan ilmu agama yang berakitan dengan spritual masyarakat juga memposisikan ulama sebagai pelurus dalam ilmu kebudayaan dan adat istiadat di ajarkan kepada santri dan masyarakat.

${ }^{21}$ M. Hasbi Amiruddin, Menatap Masa Depan Dayah di Aceh, Menatap Masa Depan Dayah di Aceh, (Banda Aceh: Yayasan PeNA 2013, Cet, Ke-III ), 120.

${ }_{22}^{2}$ M. Hasbi Amiruddin, Jihad Membangun Peradaban, (Banda Aceh: LSAMA 2015), 42.

${ }^{23}$ Muliadi Kurdi, Aceh di Mata Sejarawan, 184.

${ }^{24}$ Muhammad Thalal, dkk, Ulama Aceh Dalam Melahirkan Human Resource di Aceh, 13. 
Sebagaimana dalam catatan sejarah menasah dan dayah dijadikan sebagai tempat untuk membina dan membentuk akhlak masyarakat yang jauh berlangsung pada zaman sultan Iskandar Muda. Dayah dan menasah dijadikan sebagai tempat institusi terpenting dan startegias terhadap pendidikan umat kala itu, dalam hal tersebut bisa dilihat dari segi aktifitas ulama di dayah, maka dengan demikian menash dan dayah berarti tempat mendidik anak pada zaman dahulu selain sebagai tempat melaksanakan peribatan juga tempat musyawarah yang berkaitan dengan kesejahteraan hidup umat, selain itu juga dijadikan sebagai tempat pengajian, tempat mengadakan kegiatan memperingati hari-hari besar Islam. Serta dijakdikan sebagai pusat penyelesaian persengketaan yang terjadi dalam masyarakat yang tidak lepas kaitannya agama Islam. Dari aktifitas ulama ditengah masyarakat dapat diakumulasikan bahwa ulama orang pertama yang memobilisasi pendidikan didayah dan meunasah ulama berada pada garda terdepan sekaligus aktor utama dalam mendidik umat manusia. ${ }^{25}$

Peran ulama Aceh sangat besar dalam menyiarkan agama Islam, membina umat manusia dan menjalankan roda pedidikan pendidikan, hingga membantu pemerintahan. kedalaman ilmu, kemempuan komunikasi, contoh aplikasi langsung pengalaman, dan sifat-sifat dasar ulama membuat mereka mendapat kedudukan terhormat di tengah masayarakat sehingga ilmu yang mereka sampaikan di pelajari sungguh-sungguh oleh muridnya dan perintah mereka di ikuti dengan keikhalsan ${ }^{26}$

Ulama di Aceh sudah senantiasa melakukan aktifats dakwah dalam membina umat masnusia kearah yang jauh lebih baik, agar umat manusia selalui melakukan perbuatannya sesuai dengan perintah agama dengan tujuan agar masyarakat selamat dari pebuatan dosa dan hidup bahagia didunia maupun diakhirat, oleh karena itu ulama mempunyai nilai kedukannya yang tinggi dalam masyarakat dan kehadiran sosok ulama begitu penting ditengah-tengah umat.

Kedukukan yang mulia seorang ulama ditengah masyarakat tidak begitu lahir begitu saja, akan tetapi itu semua kerana proses perjuangan dan keikhlasan

${ }^{25}$ Muhammad Thalal, dkk, Ulama Aceh Dalam Melahirkan Human Resource di Aceh, 13-

${ }^{26}$ M. Thamrin, Edy Mulyana, Perang Kemerdekaan Aceh, Z. Edy Mulyana, Perang Kemerdekaan Aceh, (Banda Aceh: Badan Perpustakaan Provinsi Nanggro Aceh Darussalam, 2007), 106. 
dalam memberikan kontribusinya terhadap umat dan dalam mensehati para raja pada zaman dahulu yang sangat tulus, seperti misalnya keptusan raja diambil setelah adanya berkonsultasi dengan para ulama pada konteks yang berkaitan dengan keagamaan. Sebelum para penjajah datang dari benua eropa sosok ulama di daerah Aceh telah lebih awal dijadikan sebagai panutan terhadap perkembngan tradisi keIslaman dan keilmuan. Dan tidak sedikitpun dari kalangan ulama mengembangkan ajaran Islam kedaerah lain di sumatera barat dan pulau Jawa, bukan hanya sampai disitu saja ulama juga memainkan perannya melalui tullisantulisan yang sampai sekarang masih ada pertinggalnya dan dijadikan sebagai bahan rujukan dalam tradisi keilmuan Islam di Nusantara. ${ }^{27}$

Selanjutnya selain menasah, ulama juga menjadikan dayah sebagai tempat pendidikan yang khas di Aceh melalui dayah sosok ulama berkpirah membina umat manusia kejalan yang diridhai oleh Allah Swt. Artinya kalangan ulama di Aceh telah mengembankan keulamaannya melalui pemberian kontribusi yang religius perannya juga dibidang pertahanan politik (Siyasah). Dalam sejarah Aceh dapat dicermati pasang surutnya peranan ulama sampai saat ini. ${ }^{28}$

\section{Peran Ulama Melawan Belanda dan Konflik-Konflik di Aceh}

Pada saat meletusnya perang Aceh pada 5 april tahun 1873, ulama berperan sebagai komando yang berdiri dibarisan terdepan melawan para Belanda yang hendak menjajah Aceh pada masa itu, ulama memberikan motivasi menggerakkan semangat juang rakyat melawan orang kafir, bukan hanya sekedar motif negara akan tatapi juga dilandasi oleh semangat membela agama Islam dari ancaman orang-orang belanda. ${ }^{29}$ Dengan ketaatan dan eksisitensinya seorang ulama terhadap agama Islam telah dapat menggerakakan hati rakyat untuk berjuang dengan ikhlas mengusir belanda di Aceh, seorang ulama juga memiliki berbagai kelebihan pemberian sang Maha Pencipta, misalnya koramah (kemulian, kekeramatan) dan kedekatannya dengan Allah SWT. maka tidak heran ketika rakyat Aceh berperang

27 Kamaruzzaman Bustaman Ahmad, Membangun Kembali Jati Diri Ulama Aceh, Pengantar M. Hasbi Amiruddin, Ulama Dayah: Pengawal Agama Masyarakat Aceh (Lhokseumawe: Nadiya Foundation, 2003), xi-xii.

${ }^{28}$ Sri Suryanta, Dinamika Peran Ulama, (Yogyakarta: AK.Group, UIN Ar-Raniry Banda Aceh, 2008, Cet, I), 175.

${ }^{29}$ Muliadi Kurdi Aceh di Mata Sejarawan, 185 
melawan orang kafir dengan ikhlas dikarenakan ulama mempunyai kelebihan dalam memberikan semangat kepada rakyat.

Ulama memotivasi dan memimpin jihad fisabilillah ketika itu, sehingga terciptalah ideologi perang sabil. Dalam mensosialisaikan ideologi perang sabil ulama memanfaat perkakas perang seperti senjata rencong yang dibuat berbentuk basamallah demi keteguhan hati rakyat mengingat Allah dalam berperang, dan menuliskan ayat suci-suci serta kata-kata hikmah pada bendera agar dapat mengunggah semangat masyarakat untuk jihad fi sabilillah. ${ }^{30}$

Peran ulama ulama dalam realitas politik Islam Islam begitu besar, walaupun sebagian mereka tidak melibatkan diri dalam kancah politik secara langsung, dengan mengambil alternatif mengasingkan diri terhdap keramain dan dalam politik dan kekuasaan, lebih fokus dan khusyuk memndidik masyarakat di dayah yang bebas dari aneka ragam pengaruh. Dalam hal ini bukan berarti tidak menghiraukan lagi sama sekali tanggung jawabnya terhadap pilitik. Akan tetapi juga berperan dalam bnetuk do'a kepada Allah Swt. terhadap perannya dibidang politik. $^{31}$

Masyarakat Aceh memandang ulama sebagai pemimpin agama yang dapat memberikan energi umat Islam dalam melakukan sesuatu tindakan, oleh sebab itu pemerintahan Belanda menjaga ketat gerakan ulama karena Belanda menagukui bahwa ulama sosok yang dapat memobilisasi rakyat melalui ketaatan spritual yang dimiliki ulama. Christian Snouk Hurgronje (1857-1936),yang dinilai oleh Harry J. yang kemudian di ikuti oleh Aqib Suminto sebagai peletak dasar politik Islam di Hindia Belanda, membedakan bahwa Islam merupakan agama kuat ritual ibadah selain itu Islam juga menjadi kekuatan sosial politik. ${ }^{32}$

Pada akhir bulan agustus tahun 1872 Gubernur jenderal Belanda Hindia mengirimkan sepucuk surat kepada Sultan Mahmud Syah yang merupakan kerajaan Aceh Darussalam ketika itu, surat tersebut diterima oleh kerajaan Aceh yang mana surat tersebut berisi agar Aceh tunduk pada penjajah Belanda, akan tetapi Sultan Mahmud Syah menolak permintaan tersebut serta kerajaan Aceh masa itu terus

\footnotetext{
${ }^{30}$ Sri Suryanta, Dinamika Peran Ulama Di Aceh, 176.

${ }^{31}$ Masdar F. Mas'udi, Kyai dan Kekuasaan, dalam Pesantren No. 2 vol. V, 1988, 2.

${ }^{32}$ Sri Suryanta, Dinamika Peran Ulama Di Aceh, Pengantar Hasbi Amiruddin, 69.
} 
merangkul rakyat melakukan konsolidasi untuk mendapatkan kekuatan dari rakyat dinatara kekuatan yang andalah adalah kekuatan ulama. ${ }^{33}$

Merangkul para ulama suatu hal yang utama karena ulama di anggap sangat penting keberadaan ulama dominannya dalam masyarakat maka merangkul para ulama suatu hal yang utama karena ulama di anggap sangat besar pengaruhnya, masyarakat mengaggap ulama bukan hanya sekedar sosok yang mempunyai yang ilmu pengetahuan agama namun lebih dari sekedar itu, dalam tubuh mereka terdapat suatu unsur-unsur kepemimpinan, sosok pahlawan dan pemangku agama dengan demikian ulama dapat memimpin masyarakat dengan efektif. ${ }^{34}$

Ulama juga sebagai penasehat para raja pada masa zaman dulu, oleh karena itu segala pedapat ulama dapat dijadikan dalam sebuah kebijakan kerajaan pada bidang keagamaan, sosok ulama menjadi panutan dalam masyarakat karena sangat aktif melakukan dakwahnya. Maka dengan demikian telah banyak para ulama yang kemudian menyebarkan agama Islam ke daerah lain seperti Sumatera Barat dan pulau Jawa, tidak hanya berdakwah secara ucapan akan tetapi juga melalui tulisantulisannya yang sampai pada hari ini masih dijadikan pijakan ilmu keIslaman. ${ }^{35}$

Dalam cacatan sejarah Aceh selalu ada pergolakan konflik, mulai dari persoalan pembentukan negara sendiri, konflik aliran agama, perang melawan agresi potugis, konflik melawan penjajah dalam merebut dan mempertahankan kemerdekaan bersama indonesia, bahkan sampai setelah merdeka-pun konflikkonlik tersebut masih terjadi, konflik tersebut merupakan dengan orang asing atau bangsa lain. ${ }^{36}$

Konflik internal atau sesama bangsa mungkin menjadi konflik yang paling berat dirasakan oleh masyarakat Aceh dikarenakan konflik sesama dan satu bangsa, bahkan satu agama, seperti terjadi pada tahun 1953-1959 yaitu peristiwa pemberontakan DI TII. Hal ini yang hampir sama juga terjadi pemberontakan pada tahun 1976-2005 yang awal munculnya Aceh merdeka (AM), terakhir berubah menjadi Gerakan Aceh Merdeka. Berat karena konflik interen bangsa dan satu

${ }^{33}$ Rusdi Sufi, Kiprah Ulama Aceh Pada Masa Revolusi Kemerdekaan, 1945-1949, $1945-$ 1949, (Banda Aceh: Badan Arsip dan Perpustakaan Provinsi Aceh , 2012), 35.

${ }^{34}$ Rusdi Sufi, Kiprah Ulama Aceh Pada masa Revolusi Kemerdekaan, (1945-1949), 35.

${ }^{35}$ Kamaruzzaman Bustaman Ahmad, Membangun Kembali Jati Diri Ulama Aceh. xi-xii.

${ }^{36}$ M. Hasbi Amiruddin, Menatap Masa depan Dayah di Aceh, 102. 
agama yang memerlukan kisi-kisi khusus dalam penanganannya ${ }^{37}$ Dalam sejarah Islam di Aceh juga memperlihatkan ulama selalu menjadi pelerai konflik-konflik yang pernah terjadi. ${ }^{38}$

\section{Peran Ulama Pasca Konflik Aceh}

Masyarakat di Aceh menjadikan ulama sebagai tempat rujukan dalam beragama. mereka mempercayai ulama dengan memberikan fungsi sebagai guru yang dihormati, maka dengan demikian ulama memiliki kedudukan tugas dan wewenangnya didalam masyarakat dan pemerintahan, sehingga kepada ulama diberikan sebuah legimitasi melalui pembentukan sebuah lembaga yang dijuluki sebagai majelis permusyawartan ulama (MPU) dimana ulama dengan organisasinya yaitu MPU menjadi mitra kerja legislatif, eksekutif bahkan pihak yudikatif, dalam memberikan pertimbangan-pertimbangan yang berkiatan dengan kebijakan pemerintahan Aceh. ${ }^{39}$

Majelis permusyawaratan ulama Aceh didalamanya merupakan kumpulan ulama dan cendikiawan muslim mereka adalah pemikir intelektual bukan hanya sekedar mitra pemerintahan dalam menyelengarakan kebijakan, akan tetapi mereka juga pemikir dan pemberi kontribusi terhadap pembangunan Aceh setelah tsunami para ulama juga memikirkan bagaimana upaya menjaga perdamaian Aceh yang telah ditetapakan dalam Memorandum Of Understanding (MoU) Indonesia (RI) dan gerakan Aceh Merdeka (GAM), di Helsinki, Filandia, 15agustus 2005 yang lalu, supaya Aceh tetap aman. ${ }^{40}$

Menjaga perdamaian Aceh bukanlah suatu hal yang mudah dalam dalam meletak dasar-dasar pememiliharaan perdamain di Aceh, memerlukan upaya-upaya yang tepat mak dari itu dibutuhkan pemikiran yang matang untuk membangun strategi yang efektif, sistematis dan menyeluruh. Ulama dituntut untuk memberikan dukungannya terhadap upaya perdamian Aceh melalui ilmu pengetahuan yang dimiliki.

\footnotetext{
${ }^{37}$ Sri Suryanta, Dinamika Peran Ulama Di Aceh, Pengantar Hasbi Amiruddin.101-102.

${ }^{38}$ M. Hasbi Amiruddin, Menatap Masa Depan Dayah di Aceh, 102.

${ }^{39}$ Muslim Ibrahim, Peranan Ulama dalam Pembangunan Aceh Pasca Gempa-Tsunami, (Banda Aceh: Badan Arsip dan Perpustakaan Aceh, 2013), 7.

${ }^{40}$ Muslim Ibrahim, Peranan Ulama dalam Pembangunan Aceh Pasca Gempa-Tsunami, 7.
} 
Ulama memiliki integritas moral yang memahami Al-qur'an dan hadis secara dalam dan juga wawasan yang luas dan mengamlkan ilmunya, memiliki ketaban dan kejujuran, sehingga masyarakat dijadikan ulama sebagai tokoh panutan dalam kehidupan sehari-hari Oleh karena itu dengan kejujuran dan ketabahan yang dimiliki ulama dapat merangkul masyarakat agar menjaga perdamaian agar Aceh hidup tentram dan makmur. ${ }^{41}$

Pada dasarnya ulama Aceh memilki peran yang sangat luas merujuk pada peran ulama pada era Nabi yang melingkupi segala aspek kehidupan umat manusia seprti aspek agama, sosial, budaya, politik tata Negara, politik kekuasaan. Ulama berperan menjadi penegak hukum agama, penghulu dan kadi dipengadilan, pengembang pendidikan, penjaga moral umat, penasihat raja, pembahruan pemikiran termasuk hukum fiqih Indonesia, penyebar agama ke Nusantara, pejuang melawan penjajah, penggerak organisasi ulama termasuk majelis ulama, dan pemimpin masyarakat dan pemimpin wilayah. Sejarah mencatat ulama telah banyak berperan dalam berbagai aspek kehidupan masyarakat dan Negara seperti berdirinya kerajaan besar diAceh tidak terlepas dari peran-peran ulama. ${ }^{42}$

Berdasarkan uraian diatas dapat diambil sebuah kesimpulan bahwa ulama di Aceh memang telah berperan dalam untuk bangsa, agam dan negara yang tentunya sesuai dengan ilmu pengetuan dan kempuan yang dimiliki olehnya dan sesuai dengan tugas seorang ulama hingga sekarang ulama masih berperan dalam masyarakat sesuai dengan perkembangan zaman. Ulama mempunyai integritas tinggi mempertahankan kekuatan diri mereka melalui ketaatan ibadah ritual, kekuatan pendidikan didayah, selain itu juga masih mampu menyesuaikan diri dengan irama kekuatan elit politik. Dan sampai sekarang ulama masih dijadikan tempat rujukan oleh tokoh-tokoh di Aceh. Ulama terus menjalinkan kekuatan dengan alumni-alumni dayah untuk kelangsungan berjalannya pendidikan di pesantren. $^{43}$

\footnotetext{
${ }^{41}$ Muslim Ibrahim, Peranan Ulama dalam Pembagnunan Aceh Pasca Gempa, 7-8.

${ }^{42}$ Edy Mulyana, Aceh Menembus Batas. (Banda Aceh: Badan, Perpustakaan Provinsi Nanggro Aceh Darussalam, 2007) 139-140.

${ }^{43}$ Kamaruzzaman Bustaman-Ahmad. M. Hasbi Amiruddin. Ulama Aceh, Spratisme, dan Radikalisme di Aceh, (Yogyakarta: Kaukaba. 2013, Cet. I), 79-80.
} 


\section{Peran Ulama dalam Adat di Aceh}

Asal kata adat dari bahsa Arab yaitu, Al-Adah (adat) yang diartikan sebagai kebiasaan, dengan adanya kebiasaan tersebut maka akan menjadi kebutuhan dalam suatu kelompok masyarakat, pada masa pemerintahan Aceh Darussalam adat sebagai rujukan dalam menegakkan sitem pemerintahan. Dimana adat ditegakkan untuk mendukung kekohan syari'at Islam di Aceh. ${ }^{44}$

Aceh daerah syari'at Islam dan tentunya nilai-nilai adat yang tidak terlepas dari nilai syari'at Islam untuk menegakkan adat di Aceh dalam mengatasi dari berbagai persoalan masyarakat maka tentu diperlukan orang-orang yang tepat, yaitu sosok ulama yang mempunyai ilmu pengetahuan agama dan wawasan yang luas. Maka sudah tentu ulama mempunyai peran terbesar dalam mengekkan nilai-nilai adat pada kehidupan masyarakat Aceh yang sesuai dengan norma-norma agama, karena ulama sebagai penerus perjuangan Nabi yang meliputi segala aspek kehidupan umat Islam. Nilai-nilai adat yang didakwahkan oleh ulama dan majelis adat di Aceh merupakan nilai kemasyarakatan, nilai, kebenaran, akhlak, dan nilai keindahan. ${ }^{45}$

Dengan lahirnya undang-undang No 11 tahun 2006 dapat memperjelas kehadiran wadah untuk ulama dalam memangku adat di Aceh, majelis permusyawaratan ulama atau yang disingkat dengan MPU anggotanya berasal dari kalalangan cendikiawan muslim dan ulama yang menjadi mitra kerja dewan perwakilan rakyat (DPRA) pada bidang syari'at Islam, sebagaimana tercantum dalam bab ketentuan umum pada pasal satu tentang lahirnya wadah MPU.

Majelis adat Aceh dalam melaksanakan adat maka sudah dengan pasti menjalankan syari'at Islam, yang tidak lepas dari akhlak, aqoidah, muamalah dan syari'ah. Majelis adat Aceh atau yang disingkat dengan MAA menjalankan fungsinya berdasarkan Qanun Nomor 3 tahun 2004. Dalam pasal 13 ayat (1). Qanun nomor 9 tahun 2008 disebutkan mengenai sengketa dan perselisihan adat istiadat. $^{46}$

\footnotetext{
${ }^{44}$ Syaibatul Hamdi, Eksistensi Peran Majelis Adat Aceh Dalam Mensosialisasikan nilainilai Pendidikan Diwilayah Barat Selatan Aceh, Jurnal, Ar-Raniry, Vo. 5, Juni, 2018. 119-120.

${ }^{45}$ Syaibatul Hamdi, Eksistensi Peran Majelis Adat Aceh Dalam Mensosialisasikan nilainilai Pendidikan Diwilayah Barat Selatan Aceh, Jurnal, Ar-Raniry, Vo. 5, Juni, 2018. 126-129.

46 Jabbar Sabil, Jurnal Transformasi Administrasi, Volume 02, Nomor 01, Banda Aceh: PKP2A IV LAN 2012, 209-210.
} 


\section{KESIMPULAN}

Ulama Aceh pada masa dahulu bahkan sampai sekarang sudah banyak berperan dan kontribusi mulai dari melawan penjajah Belanda, hal ini sejarah mencatat pada saat perang Aceh dengan orang Belanda pada 5 april tahun 1873, ulama berperan berdiri dibarisan terdepan melawan para penjajah, gerakan ulama menjadi pengerak utama rakayat untuk berperang pada saat itu yang hendak menjajah Aceh. ulama memberikan motivasi menggerakkan semangat juang rakyat melawan orang kafir, bukan hanya sekedar motif negara akan tatapi juga dilandasi oleh semangat membela agama Islam dari ancaman orang-orang belanda, Ulama juga berperan dipasca konflik Aceh untuk dalam menjaga perdamaian agar masyarakat hidup tentram dan damai.

Namun tidak sampai disitu saja peran ulama terus bergulir sesuai situasi dan masa, ulama mendidik masyarakat dan menyebarkan ajaran Islam melalui dakwahnya membentuk nilai-nilai adat dan budaya pada msayarakat tentunya tidak terlepas dari nilai-nilai syari'at Islam, seperti membnetuk akhlak yang mulia, membentuk lingkuangan yang damai dalam masyarakat, dan memberikan pemahaman keislamannya lainya agar masyarakat bertindak tetap sesuai dengan perintah agama.

Ulama memiliki kedudukan tugas dan wewenangnya dalam pemerintahan sehingga kepada ulama diberikan sebuah legimitasi dengan membentuk suatu lembaga ulama yang dikenal dengan sebutan Majelis Permusyawartan Ulama (MPU) dimana ulama dengan organisasinya yaitu MPU menjadi mitra kerja legislatif, eksekutif bahkan pihak yudikatif, dalam memberikan pertimbanganpertimbangan yang berkaitan dengan syari'at Islam di Aceh.

Berdasar dari berbagai peran ulama yang telah penulis kemukakan diatas maka tidak dapat dipungkiri lagi bahwa ulama-ulama di Aceh telah banyak dalam masyarakat dan dipemerintahan, mulai sejak kerajaan Aceh Darussalam sebelum Belanda menjajah Aceh, hingga sampai sekarang, artinya ulama sudah beperan sesuai dengan kemampuan yang dimiliki oleh mereka masing-masing dan sesuai dengan tugas seorang ulama dan mampu menyesuaikan dakwahnya sesuai dengan perkembangan hidup dalam masyarakat. 


\section{DAFTAR PUSTAKA}

Abdullah, Zaini, Muzakarah Pemikiran Ulma Aceh. Banda Aceh: NASA, 2015.

Ahmad, Bustaman, Kamaruzzaman, Amiruddin, Hasbi, M. Ulama Aceh, Spratisme, dan Radikalisme di Aceh. Yogyakarta: Kaukaba. 2013.

. "Membangun Kembali Jati Diri Ulama Aceh", dalam, Ulama Dayah Pengawal Agama Masyarakat Aceh. Lhokseumawe: Nadiya Foundation, 2003.

Amiruddin, Hasbi. M. Jihad Membangun Peradaban, Banda Aceh: LSAMA 2015.

- Ulama Dayah: Pengawal Agama Masyarakat Aceh. Lhokseumawe: Nadiya Foundation, 2003.

Azra, Azyumardi , Ulama, Politik dan Modernisasi, dalam Ulumul Qur'an No. 7 vol. II, 1990

Daud, Abu, Sunan. Terj. Muhammad Nashiruddin Al-Albani, Jakarta: Pustaka Azzam, 2007.

Departemen Agama RI. Al-qur'an dan terjemahnya, Jakarta: PT Bumi Restu, 1974.

Hasyim, Umar, Mencari Ulama Pewaris Nabi, Surabaya: PT Bina Ilmu, Cet. II, 1983.

Hamdi, Syaibatul. Eksistensi Peran Majelis Adat Aceh Dalam Mensosialisasikan nilai-nilai Pendidikan Diwilayah Barat Selatan Aceh, Jurnal, Ar-Raniry, Vo. 5, Juni, 2018.

Ibrahim, Muslim. Peranan Ulama dalam Pembangunan Aceh Pasca GempaTsunami, Banda Aceh: Badan Arsip dan Perpustakaan Aceh, 2013.

Kurdi, Muliadi, Aceh di Mata Sejarawan, Banda Aceh: LKAS 2009.

Mas'udi, F. Masdar. Kyai dan Kekuasaan, dalam Pesantren No. 2 vol. V, 1988.

Nuriqmar, Harmen, Keramat Ulama Aceh, Banda Aceh: Badan Arsip Perpustakaan Aceh, 2009.

Sabil, Jabba, Jurnal Transformasi Administrasi, Volume 02, Nomor 01, Banda Aceh: PKP2A IV LAN 2012

Sayid Qutub, ter. Fi Dzilali Al-qur'an Beirut Libanon Ihyau AlTurats Al Araby, v, 1967.

Suryanta, Sri, Dinamika Peran Ulama, Yogyakarta: AK.Group, UIN Ar-Raniry Banda Aceh, 2008.

Thamrin. M, Mulyana, Edy. Perang Kemerdekaan Aceh, Z. Edy Mulyana, Perang Kemerdekaan Aceh, Banda Aceh: Badan Perpustakaan Provinsi Nanggro Aceh Darussalam, 2007.

Thalal, Muhammad, dkk, Ulama Aceh Dalam Melahirkan Human Resource di Aceh, Banda Aceh: Yayasan Aceh Mandiri, 2010. 